are thought to undergo receptor-mediated endocytosis. Under conditions of low $\mathrm{pH}$, the $\mathrm{E}$ dimer reorganizes itself to form a trimer ${ }^{9}$ and activates the fusion process. The residues reponsible for fusion, the so-called fusion domain, map to a highly conserved hydrophobic loop in domain II which has been implicated in the fusogenic activity of the virus ${ }^{10}$. Exactly how the $\mathrm{E}$ dimer reorganizes to form a trimer remains obscure, but from data derived from antibody probes it seems that there is a significant reorganization of domain II following the conformational change. The soluble E dimer used by Rey et al. fails to undergo the conformational change, suggesting that the additional E sequences, or perhaps the $M$ protein, may be required for inducing the remarkable change necessary to bring about membrane fusion.

Exactly how the E dimer is arranged on the virus surface, and its possible connections to the $M$ protein and to the inner nucleocapsid protein, are also unclear. The size of $\mathrm{sE}$ is too big for it to have $T=4$ symmetry but it might be consistent with $T=3$ symmetry. For example, if the glycoprotein dimer axes were placed coincident with the icosahedral and quasi two-fold axes, a rearrangement of domain II induced by changes in $\mathrm{pH}$ would bring these domains together to form trimers and abrogate the dimer contacts (see figure). At the same time this would expose the fusogenic peptide previously hidden in a pocket under the attached carbohydrate. Future studies of TBE could include cryoelectron microscopy analysis which would be useful to identify the symmetry of the virion.

The structure of the major envelope protein of a flavivirus provides us with a multitude of new questions. It also shows, once again, the resourcefulness of viruses when attacking their cellular prey.

Richard J. Kuhn and Michael G. Rossmann are in the Department of Biological Sciences, Purdue University, West Lafayette, Indiana 47907, USA.

\footnotetext{
1. Wilson, I., Skehel, J. \& Wiley, D. Nature 289. 366-373 (1981)

2. Wilson, I. A. Wiley,

D. C. \& Skehel, J. J. Nature 289, 373-378 (1981).

Weis, W. etal. Nature $333,426-431$ (1988)

4. Bullough, P. A., Hughson, F. M., Skehel, J. J. \& Wiley, D.C. Nature 371, 37-43 (1994)

5. Rey, F. A., Heinz, F. X., Mandl, C., Kunz, C. \& Harrison, S. C. Nature 375, 291-298 (1995)

6. Heinz, F. X. et al. J. Virol. 65, 5579-5583(1991).

7. Cheng, R. H. etal. Cel/ 80, 621-630 (1995).

8. Leahy, D. J., Hendrickson, W. A., Aukhil, I. \& Erickson, H.P. Science 258, 987-991 (1992).

9. Allison, S. L. et al.J. Virol. 69,695-700 (1995).

9. Allison, S. L. et al. J. Virol. 69,695-700 (1995).
10. Roehrig, J. T., Hunt, A. R., Johnson, A. J. \& Hawkes, R. A. Virology 171, 49-60 (1989).
} -PARASITISM

\title{
Mycological mystery tour
}

From the mossy depths of the spruce forests of the Olympic peninsula in Washington state comes an eldritch tale. For within these ancient forests are mushrooms growing on the living tissues of yet other mushrooms: the hosts may remain fertile but become deformed almost beyond recognition.

The pictured specimen of a Galerina species, from which grow several fruiting bodies of the parasitic Squamanita, is unusual in that it still looks like a mushroom (for scale, the cap is $6 \mathrm{~mm}$ across). It was this specimen, in part, which enabled S. A. Redhead and col. leagues to resolve a thorny taxonomic tangle which has long been the bane of mycologists (Canadian Journal of Botany 72, 1812-1824; 1994). The swollen, oddly coloured basal 'protocarpic tubers' from which Squamanita fruiting bodies were seen to emerge were so distorted that they were long thought to be parts of Squamanita itself, rather than the tissues of hosts made shapeless by possession. Redhead and colleagues now number Squamanita as one of a small number of fungal genera which are obligate para. sites of other fungi.

The story begins as long ago as 1918 , in the Netherlands. Botanists were struck by the unexpected appearance, in several locations, of a remarkable new species of fungus notable for the odour and colour of grapes, and its curiously swol. len base. A second species, odourless but bright yellow - and again with a swollen, bulb-like base - was found in Switzerland in the mid-1930s. The botanist L. Schreier, who described this species, nurtured the isolated bulbs in a darkened cellar and showed that they sprouted mushrooms in the absence of a supporting mycelium. It was this second occurrence which inspired the creation of the genus Squamanita, based largely on the presence of the basal bulb.

Several decades of mycological disquiet set in, as collectors and resear. chers suspected that Squamanita was

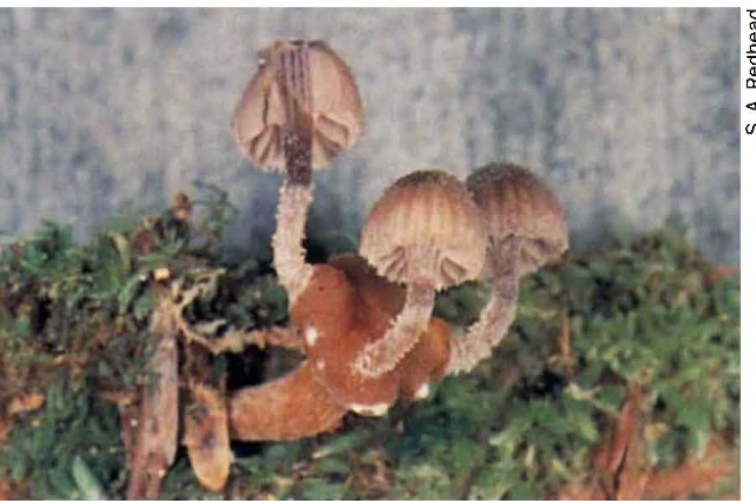

more than a fungal curio. Persistent reports of the varied character of the 'protocarpic tubers' suggested that they were less constant than taxonomic propriety demanded. More worrying were the noted resemblances between these tubers and the body parts of other fungi. One such was the agaric Cystoderma paradoxum, the stem of which seemed to be made of two different tissues, separated in the middle by an annular constriction. The tissues of the thicker bottom half were typical of its genus, but these tissues graded upwards into the thinner stalk and cap of a Squamanita. This unwholesome chimaera was removed to the genus Squamanita, the peculiar Cystodermalike base being taken as just another example of a Squamanita protocarpic tuber.

It was then that suspicions of parasitism arose, as examples of this odd species were collected from within colonies of otherwise normal examples of Cystoderma. "It seems as if another agaric has been grafted on to the stem of Cystoderma amianthinum", observed one collector. Mycologists began to view Squamanita as a changeling, parasitizing Cystoderma to the extent of perverting the tis. sues destined to be the upper stalk and cap of the mushroom to its own image - giving the appearance of a Squamanita growing from a tuber with an uncanny resemblance to Cystoderma.

Support for this idea came from Japan, with the discovery in 1990 of an example of Squamanita with a protocarpic tuber bearing characteristic features of another fungus, Phaerolepiota aurea. The clear-cut parasitism of Squamanita on specimens of Galerina from the Olympic peninsula now unequivocally ex. poses the relationship between host and unwelcome guest.

The solution raises another problem. The genus Squamanita is traditionally defined on the presence of the basal tuber. But this is invalid if these tubers are really the shattered wrecks of other fungi. Redhead and colleagues pick their way out of the impasse to justify the existence of Squamanita as a cadre of obligate parasites of fungi, and then review all other similar instances. The result is an enjoyable snapshot of some 80 years of thinking about the phenomenon. Henry Gee 